\title{
IMPACT OF FREE ECONOMIC ZONES ON REGIONAL ECONOMIC DEVELOPMENT: THE CASE OF KLAIPEDA FREE ECONOMIC ZONE IN LITHUANIA
}

\author{
Valentinas Navickas \\ School of Economics and Business, Kaunas University of Technology, Lithuania, \\ E-mail: valna@ktu.lt \\ Ieva Petroke \\ School of Economics and Business, Kaunas University of Technology, Lithuania, \\ E-mail: ieva.petroke@gmail.com \\ Vaida Baciuliene \\ School of Economics and Business, Kaunas University of Technology, Lithuania, \\ E-mail: vaida.baciuliene@gmail.com
}

Received: 22 January 2021. Revision received: 25 February 2021. Accepted: 15 March 2021

\begin{abstract}
The rapid growth of cooperation among countries, globalization, and integration has been some of the most significant indicators for the growing importance of free economic zones [FEZs] in the system of world economic relations. However, despite the advantages provided by FEZs, not all countries can successfully exploit the potential of FEZs. It is noticed that state institutions are hesitant to establish special purpose economic zones due to the difficulty of measuring the benefits of FEZs. This article aims to explain the phenomenon of the FEZ impact on regional economic development. In this article, based on the correlation analysis an algorithm is developed according to the interfaces illustrating the highest determination coefficient. The algorithm provides an opportunity to reveal the dependence on regional economic development from FEZs activity. The study reveals that the most critical FEZs activities that significantly impact regional economic development are the amount of attracted foreign direct investments [FDI], the number of companies operating in FEZ and jobs created in the zone.
\end{abstract}

KEYWORDS: free economic zone, regional development, competitive advantage, algorithm, Lithuania.

JEL CLASSIFICATION: R1, R11, R12, E2

Reference: Navickas, V., Petrokè, I., Bačiulienè, V., (2021). Impact of free economic zones on regional economic development: the case of Klaipeda free economic zone in Lithuania. International Journal of Entrepreneurial Knowledge, 9(1), 97111. Doi: $10.37335 /$ ijek.v9i1.120

\section{INTRODUCTION}

In the course of intensive globalization processes, strengthening of economic, cultural, and political cooperation between countries, the relations greatly influence the formation of trade, technology, investment, resource, and information flows (Privara and Kiner, 2020). With the constantly changing market in each region, new, effective methods like the development of FEZ are being sought that promote revenue growth, investment, exports, and local resources' rational use. It is also significant that cooperation among FEZ is becoming ever more critical and may be perceived as an instrument used to solve regional economic problems.

Lithuania is also looking for methods to stimulate the growth of foreign and local investments, the establishment of new jobs, ensuring a competitive advantage. One way to attract foreign and local capital, foster production, and modernize the economy is to establish free economic zones. 


\section{INTERNATIONAL JOURNAL OF ENTREPRENEURIAL KNOWLEDGE}

Issue X, volume X, ISSN 2336-2960 (Online)

www.ijek.org

To equitably and adequately allocate limited resources, it is essential to identify priority areas where FEZ's development would bring the most significant benefits to the region's economic development. Despite the scientific literature aimed at identifying the factors driving the development of FEZ (Emtseva, Krasova, and Mazelis, 2019; Ambroziak and Hartwell, 2018), the problem is: no algorithm has yet been developed to allocate limited resources most efficiently to promote regional economic development.

The scientific novelty of the research conducted by the authors of the article is characterized by the development of an algorithm for the positive impact of FEZs on the development of the region. The algorithm provides a basis to understanding better the impact of FEZ on the region's economic development. The research results could represent a valuable platform for the creators of economic policies and the creators of national and regional development plans. Trends in regional development lead to creating the concept of strategic investment and development packages which include necessary information of a sectoral business attractiveness, sectoral and regional productivity. The differences in regional productivity significantly influence the economic development of the countries. Also, there persist strong tendencies of widening gaps in labor productivity between prosperous and underdeveloped regions. The sectoral analyses and causal research of competitiveness factors of the individual sectors and related enterprises and conditions, where such enterprises are created and operate, are inevitable in stopping this process (Dvorsky, Gavurova, Čepel and Červinka, 2020).

The research aims - to identify the elements of FEZ activity that can also be identified as the catalyst with the most significant impact on regional economic development.

\section{Research tasks:}

1. Analyse the scientific literature related to the contribution of FEZ to regional economic development.

2. To perform a correlation analysis of Klaipeda region macroeconomic and Klaipeda FEZ indicators.

3. Develop an algorithm.

Methodology. In the theoretical part, the systematic comparative analysis and generalization of the scientific literature sources is performed. A comparative analysis was performed in the analytical-research part of Klaipeda FEZ statistical data from 2014 to 2019. The authors also used econometric methods (correlation and forecasting of statistical data for 2030 using the excel "trend" function). Data is used from activity reports submitted by the Statistics Department of Lithuania and Klaipeda FEZ annual reports.

\section{THEORETICAL BACKGROUND}

Economic development is a qualitative change that challenges the structure of the economy, including innovation institutions, behaviour, technology, and creating a favourable and attractive environment for businesses. Economic development can also be understood as distinctive development of the mobilization of human, financial, organizational, physical and natural resources, the provision of competitive services to the community and the quantity and quality of products. Moreover, it can also be described as an activity by which economic development organizers strive to solve all the community problems. Economic is treated as a critical component of the region's development, forming the basis for developing other components. Moreover, regional economic development can be defined as the development, comprehensive process of change that promotes long-term economic growth, transformation that improves the economic quality of life of society members in the community. Nowadays, the regional and spatial policy focuses on supporting the development of network connections among business entities, local authorities, and the business environment (Hajduga, Pilewicz and Mempel-Śnieżyk, 2018). Lukash and Jan (2011) point out that regional economic development can be understood as a result of regional competitiveness driven by a tendency to fight for a better economic 


\section{INTERNATIONAL JOURNAL OF ENTREPRENEURIAL KNOWLEDGE}

Issue X, volume X, ISSN 2336-2960 (Online)

www.ijek.org

position. The economic development of the region focuses on quality improvement, risk reduction, innovation and entrepreneurship, which lead to a faster and higher trajectory of economic growth at the regional and national level. The economic development of a region can also be defined as a mechanism for expanding economic actors' opportunities. These participants can be individuals, firms, or industry representatives (Feldman, Hadjimichael, \& Lanahan, 2015).

The region's economic development is the essential component of community development. It provides the community's financial resources necessary for those who want to develop the community in other aspects. The leading indicators of regional economic development, which show the viability of the market, are

- the employment rate,

- the size of the GDP product per capita,

- the number of business entities and the size of wages.

One of the forms to stimulate regional economic development is establishment of free economic zones. According to scientists (Cirera and Lakshman, 2016; Zeng 2019 et al.), free economic zones can be defined as industrial zones operating in a particular statutory area where business development benefits are granted, imported material is processed before export. In World Investment Report (2019), the United Nations [UNCTAD] described FEZ as a useful tool for boosting investment, modernizing industry, creating new jobs in the region and increasing exports. Proponents of FEZ development (Busso, Gregory, \& Kline, 2013; Wang, 2013; Alkon, 2018; Moberg, 2015) claimed that a special product processing or manufacturing zone provides unique opportunities for economic development to improve free market performance and reap economic benefits. Moberg (2015) affirmed that the FEZ is the second-best solution (the best would be a completely free market, without any local constraints) for the country to integrate into the international division of labor without trade liberalization for the whole economy. Chakraborty, Gundimeda and Kathuria (2017) pointed out that FEZ would benefit the host country by attracting foreign direct investment, creating employment, increasing exports and fostering its economic ties through technology transfer and the use of local resources. Xie, Swerts and Pumain (2018) claimed that investments in FEZs could facilitate cluster development, strengthen urban development and promote workers and highly skilled professionals' economic well-being. Similar findings are obtained by Kostiukevych et al.(2020), considering the rural communities' development due to engaging of attracting investments. Rajnoha et al. (2019) stated that FEZ has a positive impact on the region's development while promoting GDP growth and growing demand for skilled employees.

However, some authors (Brussevich, 2020; Turgel et. al., 2019; Jarosinski and Masloch, 2016) argue that the establishment of free economic zones can be harmful in terms of negative impacts to nature, local communities and because of extremely high costs for infrastructure preparation and development. It is believed that companies established in the FEZ' territory also reduce the development opportunities for other local businesses in the region. Critics of free economic zones have also emphasized that with the spread of globalization, competition between economic zones is rising and it reduces free economic zones' efficiency.

The influence of free economic zones at the national level on the example of specific countries was analyzed by Leong (2012), Jarosinski and Masloch (2016), Ambroziak and Hartwell (2019), Potter (2020) and others. According to UNCTAD, the number of active economic zones worldwide was 5,383 in 2019, presented in about 150 countries. Researchers found that the impact of FEZ on the region's development is significant and economically important, depending on the scale of FEZ activity and integration into the national economy. However, it is noticeable that although FEZ can provide an impetus for the country's economy to grow, not all economies have been able to take advantage of FEZ. Although FEZ' in countries such as Jordan, China, Malaysia and Lithuania are being successfully developed, FEZs in 


\section{INTERNATIONAL JOURNAL OF ENTREPRENEURIAL KNOWLEDGE}

Issue X, volume X, ISSN 2336-2960 (Online)

www.ijek.org

Mumbai, Nigeria and Pakistan have disappointed or modest results to local and national economic development. It can be concluded that the success formula, where the essential FEZ operational factors which had a positive impact on economic development, are not investigated and widely used. Identifying the main FEZ activities having the most impact on the region's economic development is particularly important because economic transformation can take decades.

When assessing the impact of a free economic zone on a particular region, it is essential that a region's impact can be twofold: direct and indirect. Indicators such as the zone's ability to attract sufficient foreign and domestic investment, exports and the number of new jobs created can be used to assess the direct impact of a free zone (figure 1).

Figure 1 Indicators for assessing the impact of free economic zones on the region

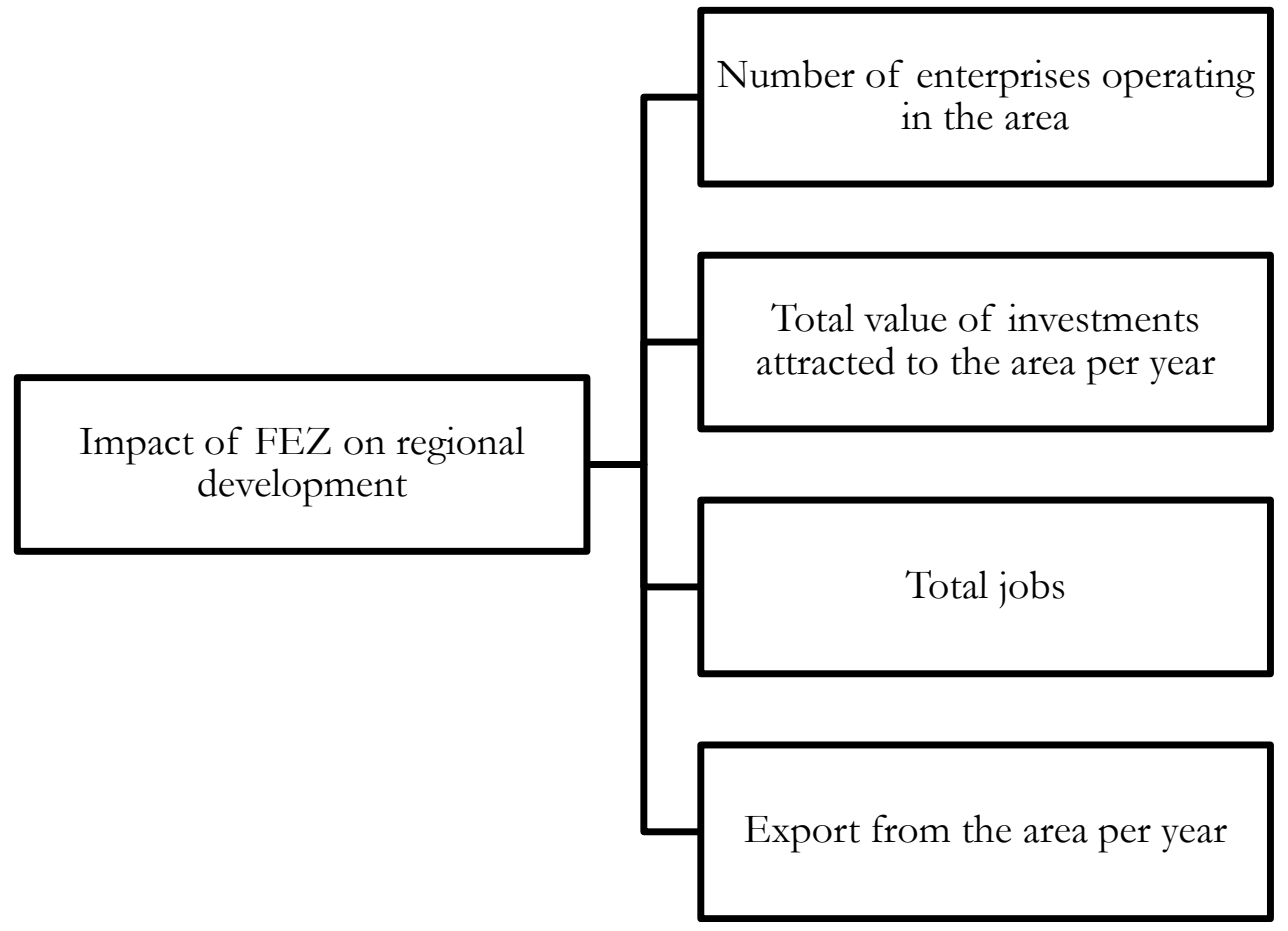

(Source: authors own construction)

The main indirect indicators of FEZ efficiency are the assimilation and implementation of new technologies, the assimilation of the latest working methods and professional development of employees, the introduction of new management and marketing methods, and market innovation strategies.

\section{METHODOLOGY}

The impact of FEZ performance indicators on a regional scale can be analyzed using different methodologies and systems. The broad impact of FEZs can cover a wide range of areas. Therefore, it can be analyzed from different perspectives using qualitative and quantitative methods or by combining them.

One possible way of assessment to conduct a study is secondary data analysis focused on the reuse of quantitative data. Information from electronic databases or an open access research repository can be used for secondary analysis. One of the secondary data analysis methods to investigate the assessment of the impact of FEZ on the economic development of the region is the measurement of the dependence 


\section{INTERNATIONAL JOURNAL OF ENTREPRENEURIAL KNOWLEDGE}

Issue X, volume X, ISSN 2336-2960 (Online)

www.ijek.org

of variables (correlation coefficient). The evaluation results allow checking the theoretical statements and to highlights the regularities of processes or phenomena. This research method was applied by Frick and Rodriguez-Pose (2019) in analyzing what is the impact of special economic zones (SEZs) in emerging countries on the economy of surrounding areas. The analysis uses the correlation method as a proxy for economic zones performance and the surrounding area's economic performance to overcome the lack of reliable economic indicators when measuring SEZ performance. The results indicate that special purpose zones positively impact the economic performance of the areas surrounding the zones beyond $50 \mathrm{~km}$.

Aiming to examine whether FEZ can attract FDI inflows to particular regions (understood as a unit of the country's administrative division), Darozynski, Swierkocki and Urbanian (2014) also used the correlation method. Calculations have shown statistically significant positive relationships between FDI inflow to SEZs and coefficients that describe the attractiveness (collective and partial) and economic advancement of voivodships. Correlation analysis was also performed to study the impact of the leading efficiency indicators of Klaipeda FEZ on the macroeconomic indicators of the Klaipeda region. The correlation analysis used in this study allowed to identify the most important FEZ factors that significantly impact the economic development of the region.

One of the most common ways to describe correlation is the Pearson correlation coefficient $r$, which quantifies the strength and direction of a linear relationship between two variables (Rodgers and Nicewander, 1988 cit. From Zhou, Zhang, \& Singh, 2016). Pearson's correlation coefficient is defined as:

$r_{w y}=\frac{\sum_{i=1}^{N}\left(x_{i}-\bar{x}\right)\left(y_{1}-\bar{y}\right)}{\left[\sum_{i=1}^{N}\left(x_{1}-\bar{x}\right)^{2} \sum_{i=1}^{N}\left(y_{1}-\bar{y}\right)^{2}\right]^{1 / 2}}$

where $\mathrm{x}$ - means the first variable,

$y$ - means the second cariable,

$\mathrm{r}$ - Pearson's correlation coefficient.

The Pearson's correlation coefficient $r$ denotes values from -1 to 1 (table 1 ).

Table 1 Evaluations fo Pearson's correlattion coefficient

\begin{tabular}{|l|l|}
\hline R meaning & Relationship (correlation) \\
\hline From 0,1 to $-0,1$ & Negligible \\
\hline From 0,1 to 0,39 and from $-0,1$ to $-0,39$ & Weak \\
\hline From 0,4 to 0,69 and from $-0,4$ to $-0,69$ & Moderate \\
\hline From 0,7 to 0,89 and from $-0,7$ to $-0,89$ & Strong \\
\hline From 0,9 to 1 and from $-0,9$ to -1 & Very strong \\
\hline
\end{tabular}

(Source: Schober, Boer \& Schwarte, 2018: 1763 - 168)

Hypotheses are raised to evaluate the correlation results: 


\section{INTERNATIONAL JOURNAL OF ENTREPRENEURIAL KNOWLEDGE}

Issue X, volume X, ISSN 2336-2960 (Online)

www.ijek.org

- $H_{1}-$ As the number of enterprises operating in the FEZ increases, the average DU in the region increases.

- $H_{2}$ - The economic development of Klaipeda region is mostly influenced by the volume of FEZ exports from the zone per year.

The tendencies of the influence of Klaipeda FEZ on the economic development of Klaipeda region are presented in the conclusions.

\section{RESULTS AND DISSCUSION}

Until 2020 from the beginning of 2006, over 100 Lithuanian and foreign capital companies were operating in the territory of Klaipeda FEZ, and 34 of them have directly signed agreements with Klaipeda FEZ management company. Two-thirds of the companies operating in Klaipeda FEZ are foreign capital. From the beginning of activities until the beginning of 2020, Klaipeda FEZ attracted 634 million Eur, which makes up $60.1 \%$ of all foreign direct investment in Klaipeda city and $44.7 \%$ in Klaipeda county. New technologies and innovative management methods are being attracted with investments from abroad; broader cooperation started. Comparing the foreign direct investments (2017) accumulated in other Lithuania regions where FEZ are operating, noticed that FEZ determines about 40\% of Klaipeda County FDI, Kaunas FEZ - 17\% of Kaunas County FDI, and Panevėžys FEZ - 4\% of its county FDI. Since the establishment of Klaipeda FEZ the state invested a total of 6.4 million to Klaipeda FEZ. However, Klaipeda FEZ has paid a total of 40.2 million since the beginning of activities. Therefore, the direct state paid more than six times only for paid taxes. It is projected that in 2030. Klaipeda FEZ will be operated by 49 (table 2) companies that have signed agreements directly with Klaipeda FEZ and 36 of them will invest in business development in the future.

Table 2 Klaipeda FEZ investment attraction indicators in $2014-2030$

\begin{tabular}{|c|c|c|c|c|c|c|c|}
\hline $\begin{array}{c}\text { Attracting } \\
\text { investments }\end{array}$ & $\mathbf{2 0 1 4}$ & $\mathbf{2 0 1 5}$ & $\mathbf{2 0 1 6}$ & $\mathbf{2 0 1 7}$ & $\mathbf{2 0 1 8}$ & $\mathbf{2 0 1 9}$ & $\mathbf{2 0 3 0}$ \\
\hline $\begin{array}{c}\text { Number of active } \\
\text { enterprises (direct } \\
\text { signatories) }\end{array}$ & 21 & 22 & 25 & 29 & 29 & 34 & 49 \\
\hline $\begin{array}{c}\text { Number of invested } \\
\text { enterprises }\end{array}$ & 16 & 18 & 20 & 21 & 22 & 27 & 36 \\
\hline $\begin{array}{c}\text { Total value of } \\
\text { investments } \\
\text { attracted to the } \\
\text { zone per year } \\
\text { (million EUR) }\end{array}$ & 29,33 & 29,18 & 24,45 & 19,56 & 11,65 & - & - \\
\hline
\end{tabular}

(Source: complied by authors, according to the FEZ activity reports from 2014 to 2019)

Developing the region's economic development is vital to promote not only FDI growth but also export volumes. Companies located in Klaipeda FEZ generate more than a quarter of the total exports of the county. 
INTERNATIONAL JOURNAL OF ENTREPRENEURIAL KNOWLEDGE

Issue X, volume X, ISSN 2336-2960 (Online)

www.ijek.org

Figure 2 Share of Klaipeda's FEZ export in Klaipeda's region export

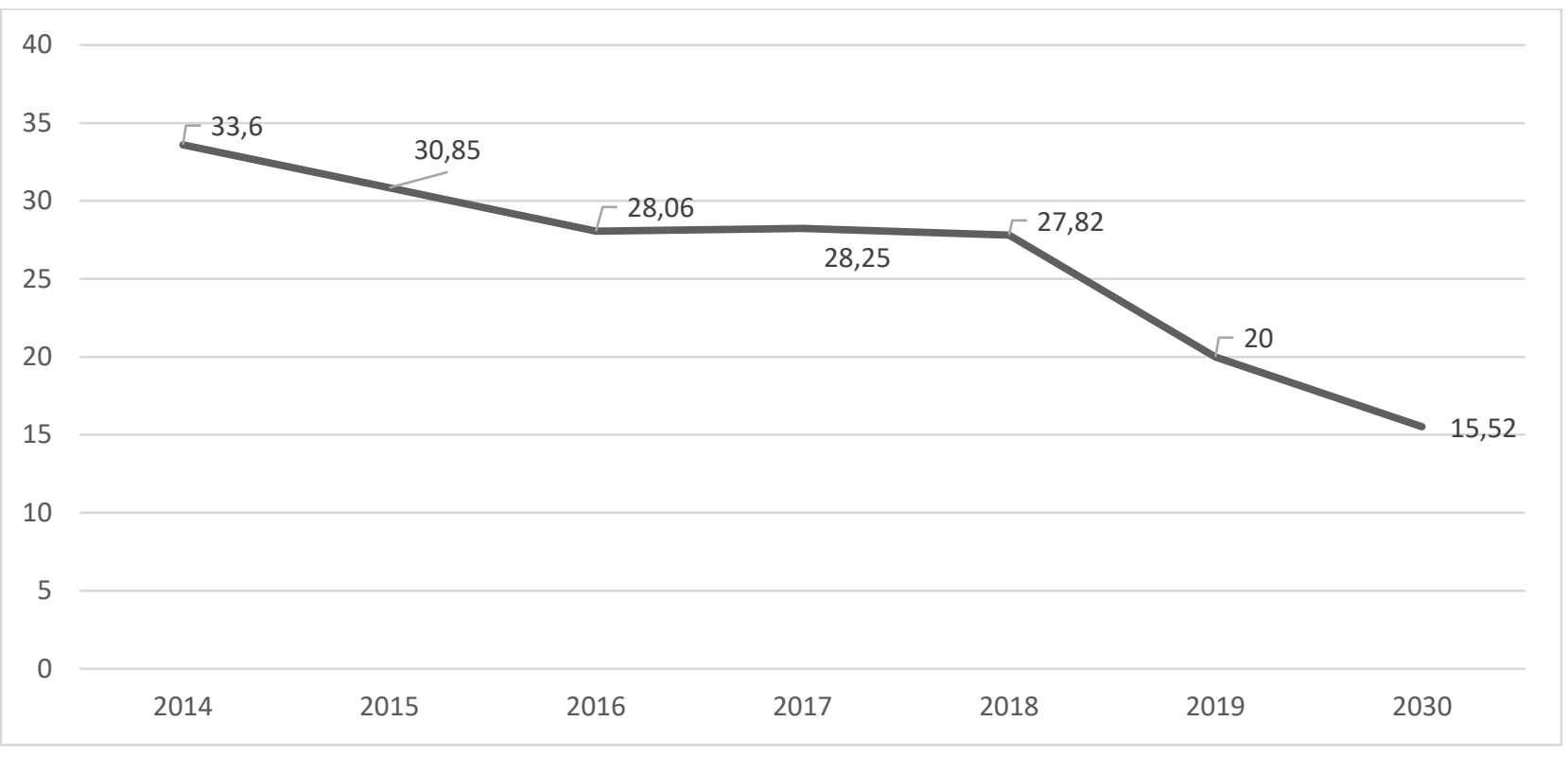

(Source: complied by authors, according to the FEZ activity reports from 2014 to 2019)

In two thousand fourteen, exports from Klaipeda FEZ accounted for 33.6 percent of Exports for the whole region. By 2020 the export volumes of Klaipeda FEZ amounted to 20\% of the Klaipeda region's total exports (Figure 2). It is believed that the declining influence of Klaipeda FEZ on exports in the Klaipeda region is determined by the successful development of Klaipeda port, the growing share of the port in the export market, and the growing number of economic entities operating in the region. Most of the Klaipeda region exports account for exports of plastics and plastic products (about 21\%) and is send to Sweden (about 11\%).

During the whole analyzed period, the share of Klaipeda FEZ export volume in the country's export market reached 2.55-2.96 percent of total country's export (Figure 3).

Figure 3 Share of Klaipeda's FEZ export in Lithuania's country export (pct.)

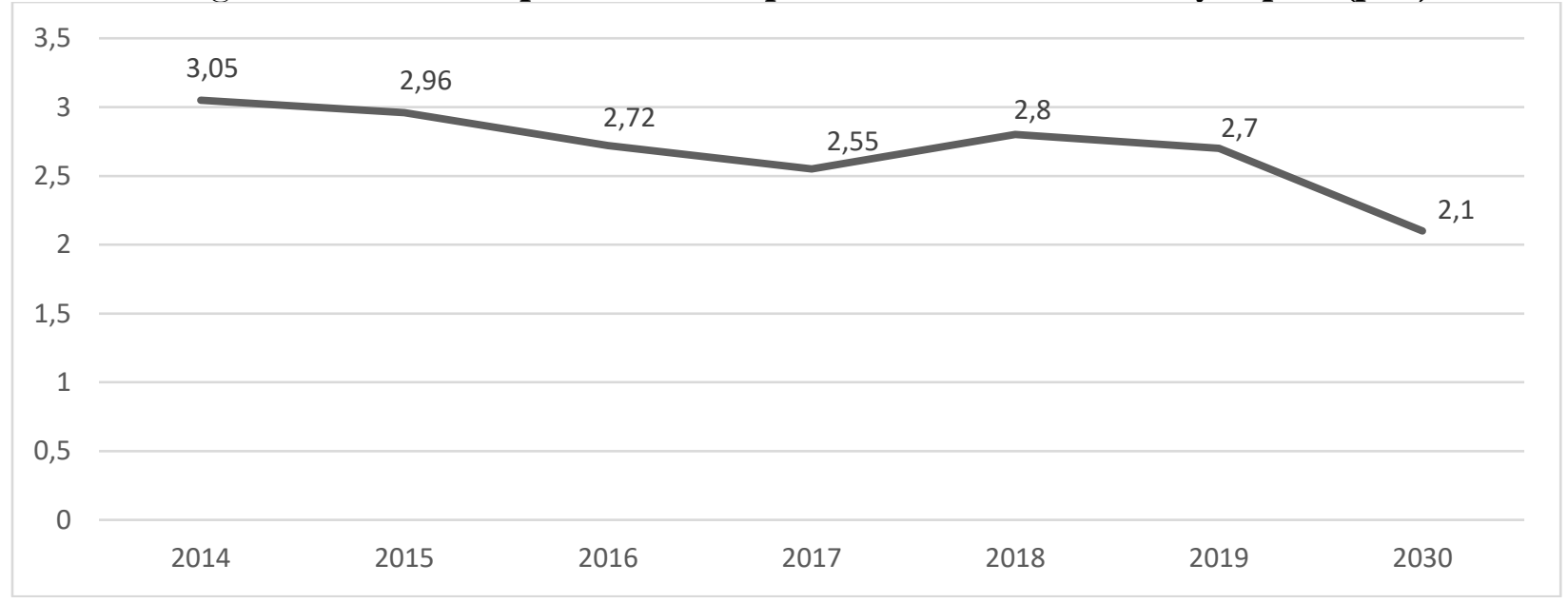

(Source: complied by authors, according to the FEZ activity reports and Lithuania Official Statistics Department from 2014 to 2019) 


\section{INTERNATIONAL JOURNAL OF ENTREPRENEURIAL KNOWLEDGE}

Issue X, volume X, ISSN 2336-2960 (Online)

www.ijek.org

From the presented graph (Figure 3) is seen that the share of exports in the domestic market from 2014 to 2016 decreases. The change can be explained by comparing export colume with 2014 when the results of FEZ activity were the best since the beginning of the company's activity. It is projected that in 2030 the contribution of Klaipeda FEZ to the country's exports should be about 2 percent due to growing competition in the market and developing new FEZ in other regions.

The presented graph (Figure 4) shows that in 2019 exports of Klaipeda FEZ decreased to $610.2 \mathrm{mln}$. EUR (or 108 million less than in 2018). According to the General Manager of the FEZ, the decrease was due to one company's decision to formally export most of its exports through a secondary trading company. It is stated that without trading through a subsidiary, exports from the FEZ in 2019 would have reached 850 million EUR.

Figure 4 Export from Klaipeda FEZ per year (million Eur), 2014 - 2030

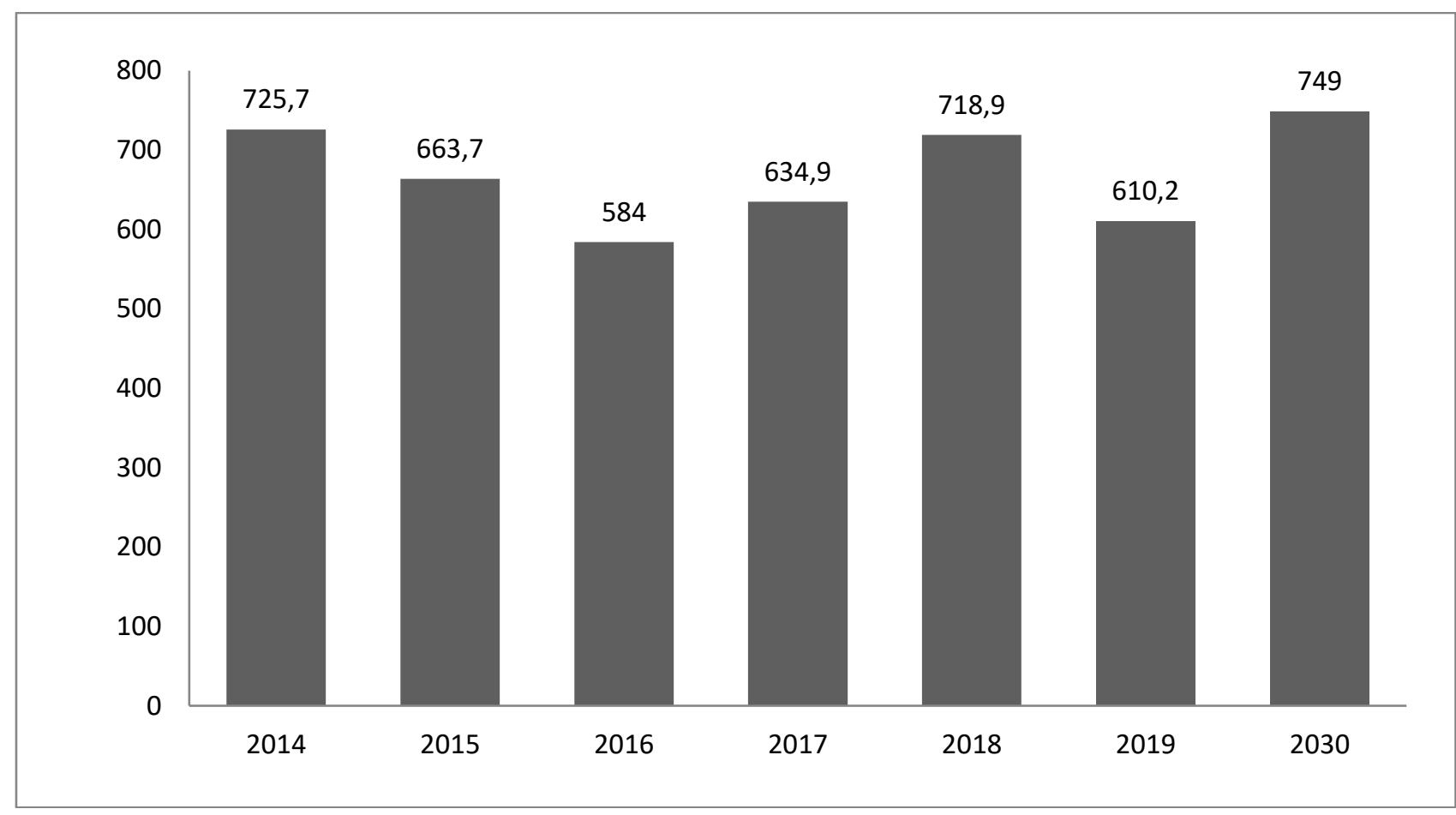

(Source: complied by authors, according to the FEZ activity reports from 2014 to 2019)

FEZ also creates new jobs through its activities (Table 3). According to the data, in 2019 Klaipeda LEZ employed 3427 employees. During the analyzed period, about 350 new jobs were created in Klaipeda FEZ every year. According to the data of 2018, Klaipeda FEZ calculates that it statistically employs approximately every twentieth working-age resident of Klaipeda city. It is projected that in 2030 about 8 thousand employees will work in Klaipeda FEZ. When compiling the forecast, based on the previous year's trends, without assessing the possibilities in the future, it is estimated that one employee will produce about 96,682 EUR in exports from the Klaipeda FEZ.

The average salary of Klaipeda FEZ in 2019 was 1177.7 euros. (it is about 40 percent more than the average resident of the Klaipeda region earned in 2018). Higher earnings in Klaipeda FEZ than in the region increase competition among employers in the market. In terms of labor productivity (exports per employee), labor productivity falls. Thus, we can conclude that it would be beneficial for the company to invest in the implementation of equipment and technologies to achieve operational efficiency. 
INTERNATIONAL JOURNAL OF ENTREPRENEURIAL KNOWLEDGE

Issue X, volume X, ISSN 2336-2960 (Online)

www.ijek.org

Table 3 Job creation in Klaipeda FEZ (companies that have signed directly with FEZ) from 2014 to 2030

\begin{tabular}{|c|c|c|c|c|c|c|c|}
\hline & 2014 & 2015 & 2016 & 2017 & 2018 & 2019 & 2030 \\
\hline Newly created jobs & 338 & 417 & 237 & 421 & 341 & 211 & 365 \\
\hline Total jobs & 1800 & 2217 & 2454 & 2875 & 3216 & 3427 & 7747 \\
\hline $\begin{array}{c}\text { Export per employee } \\
\text { (thousand Eur) }\end{array}$ & 403,16 & 299,36 & 237,98 & 220,82 & 223,53 & 178,06 & 96,682 \\
\hline
\end{tabular}

(Source: complied by authors, according to the FEZ activity reports from 2014 to 2019)

After analyzing Klaipeda FEZ efficiency indicators, we can say that Klaipeda FEZ is attractive to investors, efficiently managed. However, the company's growth rates are slowing down due to growing competition in the market and limited development opportunities in the region (declining population). The decrease in the number of attracted investments in the FEZ also impacted the declining productivity of employees (due to the lack of new technologies). The analyzed company stands out with a higher wage than the average per capita in the region. It is planned that more companies will invest in the company's activities in the future, more jobs will be created, but the influence of FEZ on the state and regional economy will decrease.

The study of the impact of Klaipeda FEZ on the economic development of the Klaipeda region analyzes the zone's ability to attract sufficient foreign and local investments, export dynamics and the number of jobs created from 2013 to 2019.

Table 4 Correlation analysis of Klaipėda's macroeconomic and Klaipeda's FEZ indicators

\begin{tabular}{|l|l|l|l|l|}
\hline & $\begin{array}{l}\text { Export from } \\
\text { FEZ }\end{array}$ & $\begin{array}{l}\text { Accumulated } \\
\text { FDI in FEZ }\end{array}$ & $\begin{array}{l}\text { Number of } \\
\text { enterprises in } \\
\text { the FEZ }\end{array}$ & $\begin{array}{l}\text { Number of } \\
\text { employees in } \\
\text { FEZ }\end{array}$ \\
\hline Kliapeda's region GDP & 0,04 & $\mathbf{0 , 6 2}$ & $\mathbf{0 , 7 4}$ & $\mathbf{0 , 8 6}$ \\
\hline Unemployment rate & $0,02$. & $\mathbf{0 , 6 1}$ & $\mathbf{0 , 9 4}$ & $\mathbf{0 , 9 8}$ \\
\hline $\begin{array}{l}\text { Operating economic } \\
\text { entities in region }\end{array}$ & 0,01 & $\mathbf{0 , 8 5}$ & $\mathbf{0 , 7 8}$ & $\mathbf{0 , 9}$ \\
\hline Wages & 0,09 & 0,1 & 0,02 & 0,01 \\
\hline
\end{tabular}

(Source: authors own calculations)

The correlation analysis showed that the dynamics of GDP in the region are related to the number of operating enterprises, employees number, and accumulated foreign direct investment in Klaipeda FEZ. While analyzing the volume of exports from the zone and GDP dynamics in the Klaipeda region, no relationship was found $\left(\mathrm{r}^{2}=0,04\right)$. A strong linear relationship is observed between: GDP per capita and operating enterprises in FEZ $\left(r^{2}=0,74\right)$; GDP per capita and employees working in Klaipeda's FEZ $\left(r^{2}\right.$ 


\section{INTERNATIONAL JOURNAL OF ENTREPRENEURIAL KNOWLEDGE}

Issue X, volume X, ISSN 2336-2960 (Online)

www.ijek.org

$=0,86)$. According to the results, it can be stated that if Klaipeda FEZ attracts more investors - more employees need to be employed, and the GDP in the Klaipeda region grows faster. The medium-strength linear relationship is observed by analyzing the accumulated FDI in FEZ and GDP per capita in Klaipeda county $\left(\mathrm{r}^{2}=0,62\right)$. The medium-strength relationship shows that the change in accumulated FDI is reflected in GDP per capita change.

Analyzing how Klaipeda FEZ's activities affect the fluctuations of the Klaipeda region's unemployment rate, a solid linear relationship with the operating companies was established $\left(r^{2}=0,94\right)$ and the number of employees $\left(r^{2}=0,98\right)$. Therefore, if more companies are operating in the FEZ, then more jobs are created in the region and the unemployment rate decreases.

The amount of accumulated FDI also contributes to the decline in the unemployment rate $\left(\mathrm{r}^{2}=0,61\right)$. A medium link could be explained by the time costs of absorbing FDI, which only directly benefits after a certain period. Even if FDI utilization efficiency is reflected in the region's declining unemployment rate, a solid correlation relationship is not seen. Conducted that there is no link between FEZ's export indicators and the unemployment rate $\left(\mathrm{r}^{2}=0,02\right)$. The first hypothesis is rejected. As the number of enterprises operating in the FEZ increases, the average DU in the region is not increases. After performing the correlation analysis, a powerful relationship was established between the dynamics of the number of economic entities operating in the Klaipeda region and those working in the Klaipeda $\left(\mathrm{r}^{2}=\right.$ $0,9)$.

A strong linear relationship was also recorded by analyzing the number of operating companies in Klaipeda FEZ and the number of operating economic entities in the region $\left(r^{2}=0,78\right)$. A strong relationship was also calculated while analyzing the number of accumulated foreign direct investments and operating economic entities in the region $\left(\mathrm{r}^{2}=0.85\right)$. Analyzing the number of operating economic entities in the region and the volume of exports from Klaipeda FEZ per year, no connection was established $\left(\mathrm{r}^{2}=0,01\right)$. The second hypothesis is rejected. The economic development of Klaipeda region is not significantly influenced by the volume of FEZ exports from the zone per year.

No statistically significant relationship was found between the change in wages and the analyzed company's economic indicators. One of the reasons can be considered that wages are determined by many factors, which depend not only on the processes taking place in the region but also on the country's policy.

Therefore, the performed correlation analysis shows that Klaipeda FEZ significantly contributes to the economic development of the Klaipeda region.

The research conducted by the authors of the article shows that the influence of FEZ on the development of the region depends mostly on the number of FEZ employees - a; the number of active enterprises $\mathrm{b}$; and the accumulated foreign direct investments - c. Based on the data, an algorithm for the positive impact of FEZ on regional development is presented. The algorithm was presented by calculating the average estimates according to the analyzed criterion and determining the criterion's coefficient, equating the sum of all significant elements to one. The algorithm did not include statistically insignificant criteria for the economic development of the region if the calculated coefficient of determination is less than 0,39 :

$$
\begin{aligned}
\mathrm{Y}=0,38 \mathrm{a}+ & 0,33 \mathrm{~b}+0,29 \mathrm{c} \\
\text { where } & \mathrm{a}-\text { number of FEZ employees, } \\
& \mathrm{b} \text { - number of active enterprises, } \\
& \mathrm{c}-\text { accumulated FDI in FEZ. }
\end{aligned}
$$


INTERNATIONAL JOURNAL OF ENTREPRENEURIAL KNOWLEDGE

Issue X, volume X, ISSN 2336-2960 (Online)

www.ijek.org

Figure 5 Impact of FEZ on the economic development of the region

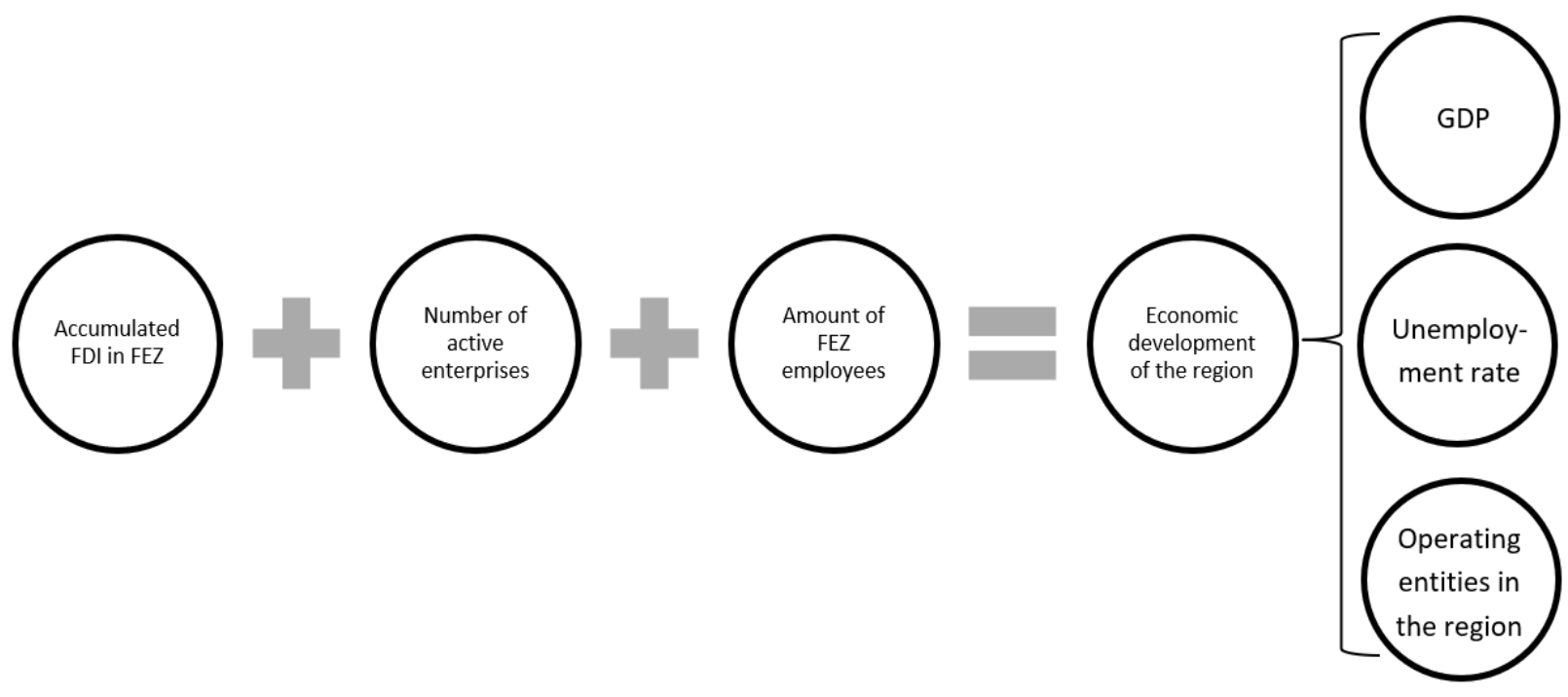

(Source: authors own constructions)

The employment indicator - a, to a large extent, is determined by the nature of the zone's main activities. It is observed that areas with productive activities create three times more jobs than those engaged in commercial activities. As the demand for labor increases, so do wages and employment. It has been established that the average salary in Klaipeda's FEZ is about 30 - 40 percent bigger than the average resident of the Klaipeda region.

Another critical factor is the number of operating companies in the FEZ - b. It is observed that with the growth of the number of employees in the FEZ, the number of economic entities operating in the region is increasing. The increase in economic entities can be explained by the fact that local suppliers supply the companies operating in the FEZ to purchase raw materials and other equipment to produce the final product. More than a third of the demand for raw materials. Thus, the more enterprises are located in the FEZs, the more economic entities serving enterprises are established.

It was found that the development of the region is also influenced by the FEZ's ability to attract sufficient foreign and local investment. Investments are directly determined by the tax benefits offered by the state and the political situation of the state itself, the regulation of various laws, the level of corruption, and other factors. Sabir, Rafique, and Abbas (2019) note that foreign direct investment also has an additional positive effect: it allows the transfer of knowledge and technology from more developed countries, has a positive impact on economic competitiveness and productivity, promotes quality improvement, and contributes to human capital development.

Limitations of the study. The authors understand that the case study has its limits. One of them is the local nature of the case study. Another limitation is the availability of statistical data, which makes it difficult to obtain data of FEZ activities. It is noted that data on FEZ in Lithuania are not publicly available, so in each case, the data must be provided by FEZ management companies. 


\section{INTERNATIONAL JOURNAL OF ENTREPRENEURIAL KNOWLEDGE}

Issue X, volume X, ISSN 2336-2960 (Online)

www.ijek.org

Research discussion and further research directions. After analyzing the FEZ performance indicators that have the most significant impact on promoting the region's economic development, we can state that the role of the FEZ in promoting the region's economic development will continue to remain at the center of academic discourse. Although the efficient operation of FEZ stimulates the economic activity of the region, it has been found that some indicators of FEZ activity have a more significant impact than others, which cannot be considered as significantly interrelated indicators. Thus, to thoroughly study the impact of FEZ on regional development, it is also vital to analyze FEZ performance indicators that do not significantly impact the region's economic development but can significantly correlate with the region's social, demographic and other indicators. The study could also be supplemented with data depicting the most favorable environmental conditions for the establishment of FEZ, thus creating a FEZ activity model. This would allow the countries to regulate the development of the region by adapting the business environment and focusing on the importance of performance indicators and their impact on the region's development. Based on the study results, the question also arises as to whether the impact of FEZ on regional development will remain the same in the future.

\section{CONCLUSION}

The region's economic, social, and investment climate depends on the activities carried out in the FEZ. Although most authors single out the potential benefits of FEZ for the region, it is difficult to predict how FEZ performance indicators transform the region's economic environment. To use FEZ efficiency for regional economic development, it is essential to identify the main elements of FEZ activity. Their development would create preconditions for the efficient functioning of the FEZ, creating better economic and competitive conditions at the local and national levels.

It was found that FEZ can be considered as a tool to enhance the potential for the development of economic activities. FEZ can attract other firms in the region that would improve product quality and diversify. It can also produce local value chains that will translate to more incredible innovation, productivity, and employment at the local level. This implies that decision-makers should adjust the strategy and set the goals accordingly while developing FEZs in the specific region.

These findings are essential for countries and areas in which FEZ does not give the expected results for regional economic development or the countries that are currently considering FEZs as a viable development tool.

Although this algorithm is based on the Klaipeda FEZ operating in Lithuania, it can be applied to other FEZ operating in any country. The algorithm evaluates the direct factors that have the most significant impact on the development of the region.

\section{REFERENCES}

Aaron, A. (2019). Special economic zones a model for the middle east and north Afrika. Retrieved from Ambroziak, A. \& Hartwell C. (2018). The impact of investments in special economic zones on regional development: the case of Poland. Regional Studies, 52(10), 1322-1331. DOI: $10.1080 / 00343404.2017 .1395005$

Bilan, Y., Mishchuk, H., Roshchyk, I. \& Joshi, O. (2020). Hiring and retaining skilled employees in SMEs: problems in human resource practices and links with organizational success. Business: Theory and Practice, 21(2), 780-791. DOI: https://doi.org/10.3846/btp.2020.12750

Brussevich, M., 2020. The Socio - economic Impact of Special Economic Zones: Evidence from Cambodia. IMF Working Paper Asia \& Pacific Department, WP/20/170, 2-26. 


\section{INTERNATIONAL JOURNAL OF ENTREPRENEURIAL KNOWLEDGE}

Issue X, volume X, ISSN 2336-2960 (Online)

www.ijek.org

Busso, M., Gregory, J. \& Kline, P. (2013). Assessing the Incidence and Efficiency of a Prominent Place Based Policy. American Economic Review, 103(2), 897-947. DOI: 10.1257/aer.103.2.897

Chakraborty, T., Gundimeda, H. \& Kathuria, V. (2017). Have the Special Economic Zones Succeeded in Attracting FDI? - analysis for india. Theoretical Economics Letters, 7, 623-642. https://doi.org/10.4236/tel.2017.73047.

Cirera, X. \& Lakshman, R. W. D. (2016). The impact of export processing zones on employment, wages and labour conditions in developing countries: systematic review. https://doi.org/10.1080/19439342.2017.1309448

Darozynski, T., Swiekocki, J. \& Urbaniak, W. (2014). Attracting FDI to the Region of Lods By Its Local Government. Comparative Economic Research, 17(2). DOI: 10.2478/cer-2014-0016

Dvorsky, J., Gavurova, B., Čepel, M. \& Červinka, M., 2020. Impact of selected economic factors on the business environment: the case of selected east European countries. Polish Journal on Management studies, 22(2), 3-15. DOI: 10.17512/pjms.2020.22.2.07

Emtseva, E.,D., Krasova, E.,V. \& Mazeli, L., S., 2019. The econometric Model of the Social and Economic Regional Development Impact on Demographic Processes. Advances in Economics, Business and Management Research, 79, 11-15. https://doi.org/10.2991/iscfec-19.2019.3

Feldman, M., Hadjimichael, T. \& Lanahan, L., 2016. The logic of economic development: a definition and model for investment. Environment and Planning C: Government and Policy, 34, 5-21. DOI: $10.1177 / 0263774 \mathrm{X} 15614653$

Formánek, T. (2019). GDP per capita in selected EU countries: Economic growth factors and spatiotemporal interactions examined at the NUTS2 level. Journal of International Studies, 12(1), 119-133. DOI: $10.14254 / 2071-8330.2019 / 12-1 / 8$

Frick, S. \& Rodriguez-Pose, A. (2019). Are special economic zones in emerging countries a catalyst for the growth of surrounding areas? Transnational corporations 26(2), 75-94. DOI: $10.18356 / 0554$ caefen

Hajuga, P., Pilewicz, T. \& Mempel-Śnieżyk, A. (2018). Cooperation between Local Authorities and Economic Entities in Polish Economic Zones - Evidence from Lower Silesia in Poland. Economics and Sociology, 11(2), 80-96. DOI 10.14254/2071- 789X.2018/11-2/6

https://www.kas.de/documents/282499/282548/Special+Economic+Zones+for+the+MENA. pdf $/ 5$ eaf7935-0b69-adee-a833e2a3298cf045?version $=1.2 \& \mathrm{t}=1575461939605>$

Jarosinski, K. \& Masloch, G. (2016). The Impact of Special Economic Zones on the Level of SocioEconomic Changes of Polish Regions. Warsaw Forum Econ. Sociol, 7, 115-137.

Klaipèda free economic zone. Retrieved from www.fez.lt. Kostiukevych, R., Mishchuk, H., Zhidebekkyzy, A., Nakonieczny, J., \& Akimov, O. (2020). The impact of European integration processes on the investment potential and institutional maturity of rural communities. Economics and Sociology, 13(3), 46-63. doi:10.14254/2071-789X.2020/13-3/3

Kostiukevych, R., Mishchuk, H., Zhidebekkyzy, A., Nakonieczny, J., \& Akimov, O. (2020). The impact of European integration processes on the investment potential and institutional maturity of rural communities. Economics and Sociology, 13(3), 46-63. DOI 10.14254/2071-789X.2020/13-3/3

Leong, C. K. (2012). Special economic zones and growth in China and India: An empirical investigation. International Economics and Economic Policy 10(4), 549-567. DOI: 10.1007/s10368-012-0223-6

Li, Y. (2021). Analysis of Regional Economic Development Differences Based on Intelligent Hybrid Algorithm. 1-12. https://doi.org/10.1155/2021/6666463

Lukash, M., \& Jan, N., 2011. Application of Econometric Panel Data Model for Regional Competitiveness Evaluation of Selected EU 15 Countries. Journal of Competitiveness, 4, 23-38. Retrieved from: https://www.researchgate.net/publication/265402109 Application of Econometric Panel Dat a Model for Regional Competitiveness Evaluation of Selected EU 15 Countries/fulltext/5 48eb8020cf214269f246006/Application-of-Econometric-Panel-Data-Model-for-RegionalCompetitiveness-Evaluation-of-Selected-EU-15-Countries.pdf 


\section{INTERNATIONAL JOURNAL OF ENTREPRENEURIAL KNOWLEDGE}

Issue X, volume X, ISSN 2336-2960 (Online)

www.ijek.org

Moberg, L. (2015). The Political Economy of Special Economic Zones. J. Institutional Economy, 11, 167190.

Naydenov, K. (2018). The role of free economic zones for the development of the regional economy. Conference: 5th SGEM International Multidisciplinary Scientific Conferences on Social Sciences and arts SGEM2018. DOI: $10.5593 /$ sgemsocial2018/5.2/S20.069

Potter, A. (2020). The Politics of Industrial Displacement: Evidence from Special Economic Zones. The University of Chicago press journals, 82 (1), 29 - 42 p. https://doi.org/10.1086/705596

Privara, A.. \& Kiner, A. (2020). Immigrant Employment in the Slovak Hospitality Industry: Profiles, Experience and Education. Journal of tourism and service, 11(21), 167 - 182. ISSN $1804-5650$. Retrieved from: https://jots.cz/index.php/JoTS/article/view/223/93.

Rabie, M., 2016. A theory of Sustainable Sociocultural and Economic Development. Palgarve Macmillan: New York

Rajnoha, R., Lesnikova, P., Stefko, R., Schmidtova, J. \& Formanek, I. (2019), "Transformations in Strategic Business Planning in the Context of Sustainability and Business Goals Setting", Transformations in Business \& Economics, 18,(2), 44-66.

Sabir, S., Rafiquw, A., \& Abbas, K. (2019). Institutions and FDI: evidence from developed and developing countries. Financial Innovation, Springer; Southwestern University of Finance and Economic, 5(1), 1-20. DOI: 10.1186/s40854-019-0123-7

Schober, P., Boer, C., \& Schwarte, L., A. (2018). Correlation Coefficients: Appropriate Use and Interpretations. Anesthesia \& Analgesia, 126(5), 1763-1768. doi: 10.1213/ANE.0000000000002864

Turgel, I., Bozhko, L., Prachieva, E., \& Naizabekov, A. (2019) Impact of zones with Special Status on the Environment (Experience of Russia and Kazakhstan). Environmental and Climate Technologies 23 (2), 102-113. DOI: 10.2478/rtuect-2019-0058.

United Nations, World Investment Report - Special Economic Zones, 2019. Retrieved from https://worldinvestmentreport.unctad.org/world-investment-report-2019/chapter-4-specialeconomic-zones/.

Xie, L., Swerts, E., \& Pumain, D. (2018). Eeconomic Development Zones nad Urban Growth in China. European journal of geography, 880. https://doi.org/10.4000/cybergeo.30143

Zeng, D., Z., 2019. Special economic zones: lessons from the global experience. PEDL synthesis paper Retrieved from https://pedl.cepr.org/sites/default/files/PEDL Synthesis Paper Piece No 1 $\underline{0 . p d f}$.

Zhou, Y., Zhang, Q., \& Singh, V. (2016). An adaptive multilevel correlation analysis: a new algorithm and case study. Hydrological Sciences Journal 61(15), 2718 - 2728. https://doi.org/10.1080/ $\underline{02626667.2016 .1170941}$

\section{BRIEF DESCRIPTION OF AUTHORS:}

\section{Prof. Ing. Dr. Valentinas Navickas}

ORCID ID: https://orcid.org/0000-0002-7210-4410

Doctor of social sciences (economics), professor at Kaunas University of Technology (Lithuania), School of Economics and Business. E-mail: valna@ktu.lt. Author of more than 360 scientific publications (including monographs published in the Czech Republic in 2013 and Slovak Republic in 2016, 2018) and scientific articles published in Lithuania and abroad. Prepared 7 doctors of social (economics) science; now, he is a research adviser of 3 persons maintaining a doctor's thesis of social (economics) science. Fields of scientific interest: free economic zones, clusterization, development economics, competitiveness, economic growth.

\section{Mgr. Ieva Petrokè}

ORCID ID: https://orcid.org/0000-0001-8937-1219 


\section{INTERNATIONAL JOURNAL OF ENTREPRENEURIAL KNOWLEDGE}

Issue X, volume X, ISSN 2336-2960 (Online)

www.ijek.org

School of Economics and Business, Kaunas University of Technology, Lithuania, e-mail: ieva.petroke@gmail.com. Fields of scientific interest: economic growth, development economics, sharing economy, free economic zones.

\section{Mgr. Vaida Bačiulienè}

ORCID ID: https://orcid.org/0000-0002-0558-432X

School of Economics and Business, Kaunas University of Technology, Lithuania, e-mail: vaida.baciuliene@gmail.com. Fields of scientific interest: economic growth, development economics, sharing economy. 